medRxiv preprint doi: https://doi.org/10.1101/2020.04.01.20048561; this version posted June 20, 2020. The copyright holder for this preprint (which was not certified by peer review) is the author/funder, who has granted medRxiv a license to display the preprint in perpetuity.

It is made available under a CC-BY 4.0 International license.

\title{
IL-6 signalling pathway inactivation with siltuximab in patients with COVID-19 respiratory failure: an observational cohort study
}

Authors: Giuseppe Gritti MD, Federico Raimondi MD, Diego Ripamonti MD, Ivano Riva MD, Francesco Landi MD, Leonardo Alborghetti, Marco Frigeni MD, Marianna Damiani MD, Caterina Micò MD, Stefano Fagiuoli MD, Roberto Cosentini MD, Ferdinando Luca Lorini MD, Lucia Gandini MD, Luca Novelli MD, Jonathan P Morgan MD, Benjamin M J Owens PhD, Karan J K Kanhai MD, Gordana Tonkovic Reljanovic, MD, Marco Rizzi MD, Fabiano Di Marco MD, Alessandro Rambaldi MD

\section{Affiliations: Azienda Socio Sanitario Territoriale Papa Giovanni XXIII Hospital,} Bergamo, Italy (G Gritti MD, F Raimondi MD, D Ripamonti MD, I Riva MD, F Landi MD, L Alborghetti, M Frigeni MD, M Damiani MD, C Micò MD, S Fagiuoli MD, R Cosentini MD, F L Lorini MD, L Gandini MD, L Novelli MD, M Rizzi MD, F Di Marco MD, A Rambaldi MD); EUSA Pharma, Hemel Hempstead, UK (J P Morgan MD, B M J Owens PhD, K J K Kanhai MD); ErgoMed PLC Guildford, UK (G T Reljanovic, MD); University of Milan, Milan, Italy (F Di Marco MD, A Rambaldi MD).

Corresponding author details: Giuseppe Gritti, UOC Ematologia, Azienda Socio Sanitaria Territoriale Papa Giovanni XXIII, Piazza OMS, 1, 24127 Bergamo, Italy

Email: g.gritti@asst-pg23.it

Telephone: +390352673684

\section{Abstract \\ Background}

Severe COVID-19 is characterised by interstitial pneumonia and hyperinflammation, with elevated levels of pro-inflammatory cytokines, such as IL-6. Effective treatments are urgently needed, and IL-6 is a rational target to reduce hyperinflammation.

\section{Methods}

An observational, control cohort, single-centre study initiated at the Papa Giovanni XXIII Hospital in Bergamo, Italy included patients with COVID-19 confirmed by a nasopharyngeal swab positive for severe acute respiratory syndrome coronavirus 2 RNA and interstitial 
pneumonia requiring ventilatory support. Patients were treated with either best supportive care and siltuximab or best supportive care alone. Propensity score matching was applied to minimise differences in baseline covariates between patient cohorts. The main outcome was mortality in siltuximab-treated patients compared with patients in the matched-control cohort.

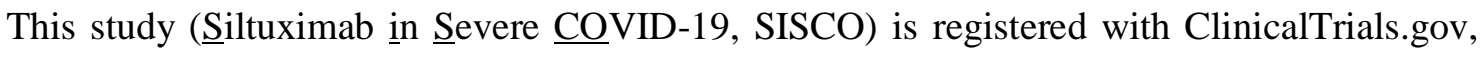
identifier NCT04322188.

\section{Findings}

Thirty patients received siltuximab, while 188 control patients received only best supportive care. Siltuximab-treated patients were matched to 30 control patients using the propensity score analysis of baseline covariates. The 30-day mortality rate was significantly lower in the siltuximab-treated than the matched-control cohort patients (HR 0.462, 95\% CI 0.2210.965); $\mathrm{p}=0.0399$ ). The mean follow-up was 33.3 days (range 7-58 days) for the siltuximabtreated patients and 22.8 days (range 2-45 days) for the control cohort. Sixteen siltuximabtreated patients were discharged from hospital, four remained on mechanical ventilation, and 10 patients died.

\section{Interpretation}

Patients with rapidly progressing COVID-19 respiratory failure requiring ventilatory support may benefit from treatment with siltuximab to reduce mortality and cytokine-driven hyperinflammation associated with severe disease. These findings require validation in a randomised controlled clinical trial.

\section{Funding}

Papa Giovanni XXIII Hospital and the Italian Association for Cancer Research funded the study. EUSA Pharma supplied siltuximab, and provided funding for data collection, analysis, and development of the publication. 
medRxiv preprint doi: https://doi.org/10.1101/2020.04.01.20048561; this version posted June 20, 2020. The copyright holder for this preprint (which was not certified by peer review) is the author/funder, who has granted medRxiv a license to display the preprint in perpetuity.

It is made available under a CC-BY 4.0 International license .

\section{Introduction}

Severe acute respiratory syndrome (SARS) and Middle East respiratory syndrome (MERS) are coronavirus infections characterised by rapid viral replication, massive inflammatory cell infiltration, and elevated levels of pro-inflammatory cytokines such as interleukin-1 (IL-1), IL-6, IL-8 and downstream proteins such as C-reactive protein (CRP), leading to acute respiratory distress syndrome (ARDS) and pulmonary injury. ${ }^{1,2}$ Similarly, infection with the severe acute respiratory syndrome coronavirus (SARS-CoV-2), the virus that causes corona virus disease, 2019 (COVID-19), also initiates hyperinflammation driven by elevated levels of cytokines. ${ }^{3}$ SARS-CoV-2 binds to alveolar epithelial cells, activating the immune system and resulting in an increase in the release of cytokines, including IL-6. These proinflammatory cytokines increase vascular permeability, leading to an increase in the amount of inflammatory exudates and blood cells entering the alveoli, resulting in dyspnoea and respiratory failure. ${ }^{4}$ Patients with severe or critical COVID-19 often develop severe interstitial pneumonia, and although the initial signs of inflammation are concentrated in the lungs, it can quickly progress to ARDS, systemic hyperinflammation, shock, and multi-organ failure leading to death. ${ }^{5,6}$ The systemic inflammation and hypoxic respiratory failure observed in severe or critical COVID-19 are associated with increases in IL-6 and CRP, which correlate with disease severity and patient prognosis. ${ }^{7,8}$ Elevated IL- 6 levels have been shown to be predictive of respiratory failure, and elevated levels of both IL-6 and IL- 8 have also been reported to be predictive of mortality. ${ }^{8,9}$

In addition to ventilatory support, targeting the IL-6 signalling pathway has been identified as a potential strategy to mitigate the elevated cytokines and resulting hyperinflammation associated with COVID-19. ${ }^{6}$ However, to date there are no data from randomised clinical trials and few controlled observational cohort studies describing the efficacy of therapies that target the IL-6 signalling pathway in patients with COVID-19.

Tocilizumab is an IL-6 receptor blocking monoclonal antibody (mAb) that is approved to treat elevated cytokines associated with the administration of chimaeric antigen receptor Tcell therapy, and received rapid approval in China for the treatment of patients with severe COVID-19 and extensive lung damage in March 2020. ${ }^{10,11}$ Reports from case series and observational studies suggest that tocilizumab has some activity in blocking the IL-6 receptor in patients with COVID-19, leading to improved oxygenation and a reduction in levels of CRP. ${ }^{11-13}$ 
In accordance with clinical guidelines developed at our medical centre, siltuximab was suggested as a treatment for hospitalised patients with COVID-19 and respiratory complications. Siltuximab is the first, and only FDA and EMA approved, mAb that specifically binds to IL-6 thereby inactivating IL-6-induced signalling. It is approved for the treatment of adults with multicentric Castleman disease who are human immunodeficiency virus and human herpes virus- 8 negative. ${ }^{14} \mathrm{We}$ examined the association between siltuximab treatment and mortality and/or respiratory function in patients hospitalised at the Papa Giovanni XXIII Hospital in Bergamo, Italy. We hypothesised that siltuximab would be associated with a low risk of mortality in analyses that were adjusted for major predictors of respiratory failure and weighted according to propensity scores to assess the drug's efficacy. 
medRxiv preprint doi: https://doi.org/10.1101/2020.04.01.20048561; this version posted June 20, 2020. The copyright holder for this preprint (which was not certified by peer review) is the author/funder, who has granted medRxiv a license to display the preprint in perpetuity.

It is made available under a CC-BY 4.0 International license .

\section{Methods}

Study design

On Mar 6, 2020, the Papa Giovanni XXIII Hospital in Bergamo, Italy made a request for siltuximab to be initially supplied under a compassionate-use programme for emergency treatment of patients with severe COVID-19. Consequently, an investigator-initiated study protocol was developed for immediate implementation. This prospective, observational cohort study was designed to report the outcomes of patients continuing to receive treatment with siltuximab under the compassionate-use programme, and retrospectively compare these outcomes to a matched-control group treated at the same centre. The study protocol was submitted and approved through the Hospital Ethics Board. Patients, or their legal representative, provided either verbal or written consent to participate in the study.

\section{Patients}

Consecutive patients with COVID-19 and interstitial pneumonia, who were hospitalised and required ventilatory support by either invasive mechanic ventilation (IMV), non-invasive ventilation (NIV) or continuous positive airway pressure (CPAP) and who met the following criteria were included in the study: diagnosis of pulmonary infection with SARS-CoV-2 confirmed by a reverse-transcriptase quantitative PCR assay; and ARDS clinical picture in accordance with the Berlin 2012 criteria. $^{15}$

Patients with an active bacterial or viral (not SARS-CoV-2) pulmonary infection not controlled by treatment were excluded from the study, and those treated with other antiinterleukin therapies, including IL-6 receptor blockers, were not eligible to participate. Those patients who were treated with siltuximab were grouped according to the type of ventilatory support received at the start of siltuximab treatment: patients receiving CPAP/NIV, and patients receiving IMV. The outcomes of patients treated with siltuximab were compared with those of patients from a control cohort who received best supportive care alone.

Patients in the control cohort were matched to the siltuximab-treated patients using a propensity score analysis. The control cohort patients were consecutively enrolled in the retrospective observational study (ReCOVID-19-2020) with the objective to describe and better understand the clinical profile of patients admitted to our institution. The ReCOVID19-2020 study was approved by the Hospital Ethics board to collect demographic data, 
medRxiv preprint doi: https://doi.org/10.1101/2020.04.01.20048561; this version posted June 20, 2020. The copyright holder for this preprint (which was not certified by peer review) is the author/funder, who has granted medRxiv a license to display the preprint in perpetuity.

It is made available under a CC-BY 4.0 International license.

patient history, symptoms, laboratory abnormalities, radiological findings and clinical outcome data.

All patients were monitored according to the hospital and Italian national guidelines for a minimum of 30 days, and if a patient was discharged from hospital they were asked to provide relevant laboratory results and safety information for 30 days following the start of treatment.

\section{Study endpoints}

The primary endpoint of this study was the reduction of mortality in COVID-19 patients treated with siltuximab compared with the matched-control cohort, calculated as the time from ventilation to death of any cause.

The secondary endpoints included the time to IMV or death in siltuximab-treated patients receiving CPAP/NIV at the time of treatment compared with the matched-control cohort. In addition, the ventilatory support parameters, respiratory function (ratio of arterial oxygen partial pressure to fractional inspired oxygen $[\mathrm{PaO} 2 / \mathrm{FiO} 2]$ ), adverse events according to the National Cancer Institute Common Terminology Criteria for Adverse Events v4.03 within 30 days of treatment, and change in serum CRP levels $(\mathrm{mg} / \mathrm{dL})$ were described in all patients who received siltuximab. Any association or correlation between serum IL-6 (pg/mL) and mortality or prognosis was explored. The study protocol is available in the supplementary materials.

\section{Clinical and laboratory evaluation}

Data were obtained from hospital medical records, and included demographic data, presenting symptoms and history of previous treatments, vital signs, ventilatory support, and laboratory data, including blood counts and aspartate aminotransferase (AST), alanine aminotransferase (ALT), creatinine, procalcitonin, lactate dehydrogenase, and IL-6, levels. Response to treatment was defined as the normalisation of CRP and blood counts, reduction in the need for ventilatory support, and the resolution of symptoms and signs of COVID-19.

\section{Confirmation of SARS-CoV-2 infection}


medRxiv preprint doi: https://doi.org/10.1101/2020.04.01.20048561; this version posted June 20, 2020. The copyright holder for this preprint (which was not certified by peer review) is the author/funder, who has granted medRxiv a license to display the preprint in perpetuity.

It is made available under a CC-BY 4.0 International license.

Patients had nasopharyngeal swab sampling, testing for SARS-CoV-2 RNA using reversetranscriptase quantitative PCR assay; patients with a positive test were considered confirmed cases of SARS-CoV-2 infection.

\section{Treatments}

Patients treated with siltuximab received a dose of $11 \mathrm{mg} / \mathrm{kg}$ administered intravenously over an hour. A second dose was permitted 72 hours after the first dose at the physician's discretion.

Best supportive care was provided according to hospital guidelines and included antiviral therapy (administration was influenced by drug availability and included lopinavir/ritonavir 200/50 mg two tablets twice daily, darunavir/cobicistat 800/150 mg one tablet once daily, or remdesivir $200 \mathrm{mg}$ administered intravenously on day 1, followed by $100 \mathrm{mg}$ daily for the remaining 9 days of treatment) and hydroxychloroquine $200 \mathrm{mg}$ twice daily. Steroid use was not permitted according to local guidelines until March 27, 2020 when high-dose corticosteroids (intravenous methylprednisolone $1 \mathrm{mg} / \mathrm{kg} /$ daily for five days or equivalent dose of oral prednisone, both followed by tapering doses) were added to the treatment guidelines. Similarly, after that date, subcutaneous prophylactic low molecular weight heparin (4000 IU once daily) was introduced in all patients at admission.

\section{Statistical analyses}

Logistic regression analyses using nearest neighbour propensity score matching were used to minimise differences in baseline covariates between patients in the control and siltuximabtreated cohorts. Patients in the control cohort were matched on a one-to-one basis with patients who received siltuximab using a number of baseline covariates at the start of ventilatory support, excluding treatment arm.

A two-sided Cox regression analysis was completed on the matched cohort analyses. For missing data points, the last observations were carried forward. All statistical analyses were performed with $\mathrm{SAS}^{\circledR}$ software (Version 9.4 or later). Descriptive statistics are given separately for the two cohorts (CPAP/NIV and IMV) and for the whole population. The safety and endpoint analyses were based on the full-analysis set.

Role of the funding source 
medRxiv preprint doi: https://doi.org/10.1101/2020.04.01.20048561; this version posted June 20, 2020. The copyright holder for this preprint (which was not certified by peer review) is the author/funder, who has granted medRxiv a license to display the preprint in perpetuity.

It is made available under a CC-BY 4.0 International license.

Papa Giovanni Hospital XXIII was the primary funding source for the study, but funding was also received by the Italian Association for Cancer Research (AIRC 5x1000 ID 21147 to A R). EUSA Pharma supplied siltuximab, and provided funding for data collection, analysis, and development of the publication. The corresponding author had full access to all the data in the study and had final responsibility for the decision to submit for publication. 
medRxiv preprint doi: https://doi.org/10.1101/2020.04.01.20048561; this version posted June 20, 2020. The copyright holder for this preprint (which was not certified by peer review) is the author/funder, who has granted medRxiv a license to display the preprint in perpetuity.

It is made available under a CC-BY 4.0 International license .

\section{Results}

Thirty patients with COVID-19 confirmed by a nasopharyngeal swab positive for SARSCoV-2 RNA and respiratory failure requiring ventilatory support were treated with siltuximab between March 7 and April 9, 2020, and 188 patients received best supportive care in the control cohort (ie, the ReCOVID-19-2020 study) between February 23 and March 13, 2020. Table $\mathrm{S} 1$ reports the baseline characteristics of all patients in the siltuximab-treated and control cohorts on the first day of ventilation.

\section{Propensity score analysis}

We completed a nearest neighbour propensity score matching analysis. The following baseline covariates were identified in the model to select a total of 30 matches between the siltuximab-treated $(n=30)$ and control cohort $(n=30)$ patients: age, time from admission to initiation of ventilatory support, CPAP/NIV or IMV ventilation, logarithmic $\mathrm{PaO} 2 / \mathrm{FiO} 2$, body mass index, comorbidities (hypertension, cardiovascular disease, cerebrovascular disease), and concomitant medication (antiplatelet therapy and angiotensin-converting enzyme $[\mathrm{ACE}]$ inhibitors). The standardised mean difference of the matched logit propensity scores for the baseline covariate was 0.0286 , which is below the recommended calliper of $0 \cdot 25$ (figure $\mathrm{S} 1$ ). Tables 1 and 2 show that baseline demographic and laboratory parameters were similar between the siltuximab-treated and matched-control patients.

\section{Siltuximab treatment}

The majority of siltuximab-treated patients were receiving CPAP/NIV at the time of treatment. They were given a single dose of siltuximab within 48 hours of initiating ventilatory support (within 24 hours: 10/25 [40.0\%]; within 48 hours: 19/25 [76.0\%]). Five patients required IMV before siltuximab treatment. Of these patients, four progressed from CPAP/NIV to IMV before siltuximab treatment, and one required IMV upon admission and was then treated with siltuximab. Six patients received a second dose 72 hours after the first dose of siltuximab. Table S2 summarises doses of siltuximab administered during the study.

\section{Comparative endpoints}

A total of 60 patients were included in the analyses for mortality, 30 in the siltuximabtreatment cohort and 30 in the matched-control cohort. The 30-day mortality rate was lower in patients treated with siltuximab than in the matched-control cohort (hazard ratio 0.462 , 95\% confidence interval [CI] 0.221-0.965); $\mathrm{p}=0.0399$ ) (figure 1). The mean follow-up was 
medRxiv preprint doi: https://doi.org/10.1101/2020.04.01.20048561; this version posted June 20, 2020. The copyright holder for this preprint (which was not certified by peer review) is the author/funder, who has granted medRxiv a license to display the preprint in perpetuity.

It is made available under a CC-BY 4.0 International license .

$33 \cdot 3$ days (range 7-58 days) for the siltuximab-treated patients and 22.8 days (range 2-45 days) for the control cohort. Although not significant there was a trend toward a reduced need for mechanical ventilation in the 25 siltuximab-treated patients on CPAP/NIV compared with the 30 matched-control patients also on CPAP/NIV (figure 2; HR 0.615; 95\% CI 0.362$1 \cdot 044)$.

\section{Non-comparative endpoints}

Figure 3 shows changes in oxygen support and outcomes for all patients treated with siltuximab. At study end, of the 30 patients 16 (53.3\%) recovered and were discharged, and four patients (13.3\%) were on IMV.

\section{Laboratory parameters}

Following treatment with siltuximab CRP levels reduced from a median of $20.7 \mathrm{mg} / \mathrm{dL}$ (IQR $12 \cdot 85-25 \cdot 30$ ) at day 1 to a median of $0 \cdot 3 \mathrm{mg} / \mathrm{dL}$ (IQR 0.1-3.9) at day 14 (figures $4 \mathrm{a}$ and $4 \mathrm{~b}$ ). Levels of liver function enzymes reduced over time in patients 30 days after treatment with siltuximab (AST: from 52.5 U/L at day 1 [IQR 40.5-74.5] to 24.5 U/L [IQR 16.5-40.0] at day 30). Lymphocyte, monocyte and leucocyte counts increased in patients following treatment with siltuximab (figure S2).

We completed a logistic regression analysis on IL-6 and although not significant, there was a trend developing between IL-6 levels and mortality (figure S3).

\section{Adverse events}

No new or unexpected drug-related adverse events were reported in siltuximab treated patients, and the majority were Grade 3 or less. Table 3 summarises the adverse events, and table 4 summarises the adverse event gradings. There were 10 deaths among siltuximabtreated patients: eight deaths were due to respiratory failure, one to multi-organ failure, and one to septic shock. The patient who died of septic shock was transferred to another hospital during the follow-up period. Of the 30 patients in the matched-control cohort, 16 patients died (cause of death data were not available).

One serious adverse event, a Grade 3 cerebrovascular event, was reported in siltuximabtreated patients. A total of 13 siltuximab-treated patients reported an infection: two were 
medRxiv preprint doi: https://doi.org/10.1101/2020.04.01.20048561; this version posted June 20, 2020. The copyright holder for this preprint (which was not certified by peer review) is the author/funder, who has granted medRxiv a license to display the preprint in perpetuity.

It is made available under a CC-BY 4.0 International license .

Grade 4 and the remaining 11 were either Grade 2 or 3. Elevations that occurred in AST and ALT were all Grade 3 and resolved by the end of the study.

\section{Discussion}

Our study is the first to report comparative data with control patients on the use of an IL-6 neutralising mAb, siltuximab, in the treatment of patients diagnosed with COVID-19 and respiratory failure. This observational cohort study included 30 patients treated with siltuximab, with 30 control patients who received best supportive care matched using a propensity score analysis to minimise differences in the baseline covariates.

At the time of designing this study, there was an urgent need for an effective treatment for patients with SARS-CoV-2 pneumonia, hyperinflammation, and respiratory failure. ${ }^{16}$ To date, many of the drugs employed to treat COVID-19 limit viral replication; however, since IL-6 drives the hyperinflammation associated with severe and critical COVID-19, inhibiting this inflammatory cytokine may control the pathological immune response. ${ }^{17}$ Results from observational studies of tocilizumab in patients with COVID-19 often requiring oxygen support rather than ventilatory support, have been mixed, with some studies showing an improvement in respiratory function, and others reporting no improvement in mortality. ${ }^{11,12,18,19}$ Although both tocilizumab and siltuximab target the IL-6 signalling pathway, their mechanism of action differs - tocilizumab is an IL-6 receptor blocker, whereas siltuximab directly neutralises IL-6, one of the key pro-inflammatory cytokines driving hyperinflammation associated with severe and critical COVID-19.,6,20

Elevated levels of pro-inflammatory cytokines and disease markers, IL-1, IL-6, IL-8, lactate dehydrogenase, ferritin and CRP, alongside low levels of lymphocytes, have been shown to correlate with clinical severity in COVID-19.,6,21 IL-6 and CRP were elevated in the siltuximab-treated patients at baseline in our study, indicative of hyperinflammation. Although hyperinflammation is a key driver of the tissue damage in COVID-19 it is still unclear when the use of immune blockers is beneficial, and whether if used too early their use could result in the development of secondary infections. ${ }^{5,22}$ In our study, patients with rapidly progressing, severe ARDS and elevated cytokines were treated with siltuximab when ventilatory support was required. Mortality rates can reach over $85 \%$ in patients requiring IMV, and therefore preventing progression of respiratory failure in patients with COVID-19 is an urgent clinical unmet need. ${ }^{23}$ Following treatment with siltuximab, the risk of death was 
medRxiv preprint doi: https://doi.org/10.1101/2020.04.01.20048561; this version posted June 20, 2020. The copyright holder for this preprint

reduced by $54 \%$ in patients on either CPAP/NIV or IMV compared with the matched-control cohort with up to 42 days of follow-up (HR=0.462; $\mathrm{p}=0.0399)$. There was a trend towards a reduction in the time to IMV or death in patients on CPAP/NIV treated in the siltuximab and matched-control cohorts, but the result was not significant. Previous studies have shown that IL-6 levels correlate with outcome; however, in our study although there was a trend towards a correlation between IL-6 levels and mortality in siltuximab-treated patients, the result was not significant, perhaps as all patients treated with siltuximab had severe disease with high IL-6 levels. ${ }^{8,9}$

In addition to improvements in mortality, laboratory data show a reduction in inflammation as evidenced by a rapid and sustained fall in serum CRP. The reduction in CRP suggests that siltuximab neutralised IL-6, as CRP is an acute-phase protein regulated by IL-6 and is an established surrogate marker. ${ }^{24}$ In addition, the normalisation of serum CRP from Day 5 onwards coincides with the observed separation of the survival curve, which supports findings that increased serum CRP and IL-6 are linked with mortality in COVID-19., ${ }^{8,9}$ Following treatment with siltuximab, more than $50 \%$ of patients were discharged from hospital, the majority within 25 days of the follow-up period, and four within 55 days of treatment. The number of patients discharged in our study are similar to those reported in the remdesivir compassionate-use study (remdesivir $47 \%$ and siltuximab 53\%). ${ }^{25}$ In the Campochiaro et al. study, $63 \%$ of tocilizumab patients were discharged within 28 days of the study. $^{26}$

Siltuximab was well tolerated and the adverse event profile in patients with COVID-19 was similar to that reported in patients with idiopathic multicentric Castleman disease. ${ }^{27}$ No adverse events were considered to be related to the study drug. Elevations in the liver function enzymes AST and ALT are often present at baseline in patients with COVID-19, and in siltuximab-treated patients all elevations were Grade 3 and resolved to normal levels over time. ${ }^{28}$ Rates of secondary infections were apparently lower than those reported in some studies with tocilizumab (13-70\% vs $43 \%$ in our study). ${ }^{19,22,26}$ In one study, tocilizumab was associated with a significant increase in secondary bacterial infections, including hospitalacquired pneumonia and ventilator-associated pneumonia. ${ }^{22}$ Those patients who did develop bacterial secondary infections in our study were mostly classed as having a Grade 3 infection, and resolved with one exception: one patient with bacteraemia progressed to septic shock and 
died during the follow-up period. Lymphocytes, leucocytes and monocytes counts increased following treatment suggesting that recovery of immune function was initiated, possibly restoring the host antiviral response. ${ }^{5,29}$

Two patients in each group received remdesivir (data not shown) as antiviral drugs were permitted as best supportive care; however, since remdesivir was given to so few patients and is most active in the early stages of COVID-19 it is unlikely to have impacted the treatment outcomes in this study. ${ }^{30}$

Our study has several limitations. It is an observational study with a small sample size, which limits the interpretation and generalisability of the results. Due to the observational study design, we cannot exclude the possibility of unmeasured confounding factors, although we have reassuringly noted consistency in the propensity score-matched analyses. No data were available for laboratory parameters and adverse events in the control cohort, meaning that comparisons between treated and untreated patients were not possible. Nonetheless, there is a sound rationale for the use of siltuximab in this patient group, and there were improvements in mortality and patient outcomes.

In summary, our study indicates that siltuximab administered at the onset of ventilatory support reduces mortality associated with COVID-19 and respiratory failure compared with best supportive care. Further randomised controlled studies are needed to confirm the efficacy and safety of this IL-6 neutralising mAb in the treatment of patients with COVID-19 and respiratory failure.

\section{Acknowledgments}

We would like to thank the patients who volunteered to participate in this study. EUSA Pharma provided the study drug, and funded the data collection, analysis, and interpretation. Data collection and analysis was completed by Eva E Alder of ErgoMed. Medical writing assistance was provided by Cheryl Jenkins of TVF Communications (London, UK). 
medRxiv preprint doi: https://doi.org/10.1101/2020.04.01.20048561; this version posted June 20, 2020. The copyright holder for this preprint (which was not certified by peer review) is the author/funder, who has granted medRxiv a license to display the preprint in perpetuity.

It is made available under a CC-BY 4.0 International license.

\section{Declaration of interests}

Jonathan Morgan, Benjamin MJ Owens and Karan JK Kanhai are employees of EUSA Pharma. Alessandro Rambaldi reports consultancy fees from Amgen, Novartis, Pfizer, Celgene, Italfarmaco, Gilead, Roche and Omeros, travel support from Amgen, Novartis, Celgene, Italfarmaco, Gilead and Roche, and research grants from Amgen, Italfarmaco and Roche, outside the submitted work. Caterina Micò reports travel support from Medac, outside the submitted work. Diego Ripamonti reports personal fees from Gilead, Janssen and ViiV, outside the submitted work. Fabiano Di Marco reports grants from Boehringer Ingelheim, GSK, Novartis and AZ, and personal fees from Boehringer Ingelheim, GSK, Chiesi, Zambon, Novartis, Guidotti/Malesci, AZ, Menarini, Mundipharma, TEVA and Almiral, outside the submitted work. Guiseppe Gritti reports non-financial support from Gilead Kite, Roche, Takeda and Janssen, and personal fees from Gilead Kite, Autolus, Roche, IQvia, Takeda, Amgen and Italfarmaco, outside the submitted work. Ivano Riva reports travel support from Aferetica outside the submitted work. Stefano Fagiuoli reports grants from Gilead and Novartis and personal fees from Gilead, Abbvie, MSD, Novartis, Bayer, Astellas, Kedrion, and Intercept, outside the submitted work. All other authors declare no competing interests. 
medRxiv preprint doi: https://doi.org/10.1101/2020.04.01.20048561; this version posted June 20, 2020. The copyright holder for this preprint (which was not certified by peer review) is the author/funder, who has granted medRxiv a license to display the preprint in perpetuity.

It is made available under a CC-BY 4.0 International license .

\section{References}

1 Kim ES, Choe PG, Park WB, et al. Clinical progression and cytokine profiles of Middle East respiratory syndrome coronavirus infection. J Korean Med Sci 2016; 31: 1717-25.

2 Channappanavar R, Perlman S. Pathogenic human coronavirus infections: causes and consequences of cytokine storm and immunopathology. Semin Immunopathol 2017; 39: 529-39.

3 Mehta P, McAuley DF, Brown M, et al. COVID-19: consider cytokine storm syndromes and immunosuppression. Lancet 2020; 395: 1033-4.

4 Zhang C, Wu Z, Li J-W, Zhao H, Wang G-Q. Cytokine release syndrome in severe COVID-19: interleukin-6 receptor antagonist tocilizumab may be the key to reduce mortality. Int J Antimicrob Agents 2020; 55: 105954.

5 McGonagle D, Sharif K, O'Regan A, Bridgewood C. The role of cytokines including interleukin-6 in COVID-19 induced pneumonia and macrophage activation syndromelike disease. Autoimmun Rev 2020; 19: 102537.

6 Siddiqi HK, Mehra MR. COVID-19 illness in native and immunosuppressed states: A clinical-therapeutic staging proposal. J Heart Lung Transplant 2020; 39: 405-7.

7 Chen X, Zhao B, Qu Y, et al. Detectable serum SARS-CoV-2 viral load (RNAaemia) is closely correlated with drastically elevated interleukin 6 (IL-6) level in critically ill COVID-19 patients. Clin Infect Dis 2020; published online April 17. DOI:10.1093/cid/ciaa449.

8 Herold T, Jurinovic V, Arnreich C, et al. Elevated levels of interleukin-6 and CRP predict the need for mechanical ventilation in COVID-19. J Aller Clin Immunol 2020; published online May 18. DOI:10.1016/j.jaci.2020.05.008.

9 Del Valle DM, Kim-schulze S, Hsin-hui H, et al. An inflammatory cytokine signature helps predict COVID-19 severity and death. medRxiv 2020; DOI: 2020.05.28.20115758.

10 National Health Commission of China. Treatment Guidelines for COVID-19. httpwww.nhc.gov.cnyzygjsmaebbfeddaf.shtml. V7. (accessed Jun 3, 2020)

$11 \mathrm{Xu} \mathrm{X}$, Han M, Li T, et al. Effective treatment of severe COVID-19 patients with tocilizumab. Proc Natl Acad Sci USA 2020; 117: 10970-5.

12 Sciascia S, Aprà F, Baffa A, et al. Pilot prospective open, single-arm multicentre study on off-label use of tocilizumab in patients with severe COVID-19. Clin Exp Rheumatol 2020; 38.

13 Toniati P, Piva S, Cattalini M, et al. Tocilizumab for the treatment of severe COVID-19 pneumonia with hyperinflammatory syndrome and acute respiratory failure: A single center study of 100 patients in Brescia, Italy. Automun Rev 2020; 19: 102568. 
medRxiv preprint doi: https://doi.org/10.1101/2020.04.01.20048561; this version posted June 20, 2020. The copyright holder for this preprint (which was not certified by peer review) is the author/funder, who has granted medRxiv a license to display the preprint in perpetuity.

It is made available under a CC-BY 4.0 International license.

14 EUSA Pharma. SYLVANT summary of product characteristics. https://www.ema.europa.eu/en/documents/product-information/sylvant-epar-productinformation_en.pdf (accessed Jun 3, 2020).

15 ARDS Definition Task Force, Ranieri VM, Rubenfeld GD, et al. Acute respiratory distress syndrome: the Berlin Definition. JAMA 2012; 307: 2526-33.

16 Graselli G, Zangrillo A, Zanella A, et al. baseline characteristics and outcomes of 1591 patients infected with SARS-CoV-2 admitted to ICUs of the Lombardy region, Italy. JAMA 2020; 323: 1574-1581

17 Ingraham NE, Lotfi-Emran S, Thielen BK, et al. Immunomodulation in COVID-19. Lancet Respir Med 2020; published online May 4. DOI:10.1016/S2213-2600(20)302265.

18 Colaneri M, Bogliolo L, Valsecchi P, et al. Tocilizumab for treatment of severe COVID19 patients: preliminary results from SMAtteo COvid19 REgistry (SMACORE). Microorganisms 2020; 8: 695.

19 Quartuccio L, Sonaglia A, McGonagle D, et al. Profiling COVID-19 pneumonia progressing into the cytokine storm syndrome: results from a single Italian Centre study on tocilizumab versus standard of care. $J$ Clin Virol 2020; DOI: 10.1016/j.jcv.2020.104444

20 Moore JB, June CH. Cytokine release syndrome in severe COVID-19. Science 2020; 368: $473-4$.

21 Zhou $\mathrm{F}, \mathrm{Yu} \mathrm{T}, \mathrm{Du} \mathrm{R}$, et al. Clinical course and risk factors for mortality of adult inpatients with COVID-19 in Wuhan, China: a retrospective cohort study. Lancet 2020; 395: $1054-62$.

22 Kimmig LM, Wu D, Gold M, et al. IL6 inhibition in critically ill COVID-19 patients is associated with increased secondary infections. medRxiv 2020; DOI: 2020.05.15.20103531.

23 Richardson S, Hirsch JS, Narasimhan M, et al. Presenting Characteristics, Comorbidities, and Outcomes Among 5700 Patients Hospitalized With COVID-19 in the New York City Area. JAMA 2020; 323: 2052-9.

24 Tanaka T, Kishimoto T. The biology and medical implications of interleukin-6. Cancer Immunol Res 2014; 2: 288-94.

25 Grein J, Ohmagari N, Shin D, et al. Compassionate Use of Remdesivir for Patients with Severe Covid-19. N Engl J Med 2020; : NEJMoa2007016.

26 Campochiaro C, Della-Torre E, Cavalli G, et al. Efficacy and safety of tocilizumab in severe COVID-19 patients: a single-centre retrospective cohort study. E J Intern Med 2020; published online May 22. DOI:10.1016/j.ejim.2020.05.021.

27 van Rhee F, Casper C, Voorhees PM, et al. Long-term safety of siltuximab in patients with idiopathic multicentric Castleman disease: a prespecified, open-label, extension analysis of two trials. Lancet Haematol 2020; 7: e209-17. 
medRxiv preprint doi: https://doi.org/10.1101/2020.04.01.20048561; this version posted June 20, 2020. The copyright holder for this preprint (which was not certified by peer review) is the author/funder, who has granted medRxiv a license to display the preprint in perpetuity.

It is made available under a CC-BY 4.0 International license .

28 Garrido I, Liberal R, Macedo G. COVID-19 and liver disease - what we know on 1st May 2020. Aliment Pharmacol Ther 2020; published online May 13. DOI:10.1111/apt.15813.

29 Mazzoni A, Salvati L, Maggi L, et al. Impaired immune cell cytotoxicity in severe COVID-19 is IL-6 dependent. J Clin Invest 2020; published online May 28. DOI:10.1172/JCI138554.

30 Singh AK, Singh A, Singh R, Misra A. Remdesivir in COVID-19: A critical review of pharmacology, pre-clinical and clinical studies. Diab Metab Synd: Clin Res Rev 2020; 14: 641-8. 
Tables and Figures

Table 1: Baseline patient and disease characteristics for the matched-control cohort and siltuximab-treated patients

\begin{tabular}{|c|c|c|c|c|}
\hline & $\begin{array}{l}\text { Siltuximab-treated } \\
\text { patients, CPAP/NIV } \\
n=25\end{array}$ & $\begin{array}{l}\text { Siltuximab-treated } \\
\text { patients, } \\
\text { IMV } \\
\text { n=5 }\end{array}$ & $\begin{array}{l}\text { All } \quad \text { siltu } \\
\text { patients } \\
\text { n=30 }\end{array}$ & $\begin{array}{l}\text { Control } \\
\mathrm{n}=30\end{array}$ \\
\hline \multicolumn{5}{|l|}{ Sex } \\
\hline Male & $19(76.0 \%)$ & $4(80 \cdot 0 \%)$ & $23(76 \cdot 6 \%)$ & $24(80 \cdot 0 \%)$ \\
\hline Female & $6(24 \cdot 0 \%)$ & $1(20 \cdot 0 \%)$ & $7(23 \cdot 3 \%)$ & $6(20 \cdot 0 \%)$ \\
\hline \multicolumn{5}{|l|}{ Age, years } \\
\hline Median (IQR) & $64(58-69)$ & $64(53-65)$ & $64(57-66)$ & $64.5(56-70)$ \\
\hline \multicolumn{5}{|l|}{ Height, cm } \\
\hline Median (IQR) & $175(168-180)$ & $175(170-180)$ & $175(168-180)$ & $175(172-180)$ \\
\hline \multicolumn{5}{|l|}{ Weight, kg } \\
\hline \multicolumn{5}{|l|}{ Comorbidities } \\
\hline Hypertension & $11(44 \cdot 0 \%)$ & $1(20 \cdot 0 \%)$ & $12(40 \cdot 0 \%)$ & $11(36 \cdot 7 \%)$ \\
\hline Diabetes & $6(24 \cdot 0 \%)$ & 0 & $6(20 \cdot 0 \%)$ & $5(16 \cdot 7 \%)$ \\
\hline Cardiovascular disease & $4(16 \cdot 0 \%)$ & 0 & $4(13 \cdot 3 \%)$ & $4(13 \cdot 3 \%)$ \\
\hline Malignancies & $2(8 \cdot 0 \%)$ & $1(20 \cdot 0 \%)$ & $3(10 \cdot 0 \%)$ & 0 \\
\hline Cerebrovascular disease & $1(4 \cdot 0 \%)$ & 0 & $1(3 \cdot 3 \%)$ & $3(10 \cdot 0 \%)$ \\
\hline Chronic kidney disease & $1(4 \cdot 0 \%)$ & 0 & $1(3 \cdot 3 \%)$ & $1(3 \cdot 3 \%)$ \\
\hline \multicolumn{5}{|l|}{ Medications at baseline } \\
\hline Antiplatelet therapy & $4(16 \cdot 0 \%)$ & 0 & $4(13 \cdot 3 \%)$ & $6(20 \cdot 0 \%)$ \\
\hline ACE inhibitors & $2(8 \cdot 0 \%)$ & 0 & $2(6 \cdot 7 \%)$ & $3(10 \cdot 0 \%)$ \\
\hline Angiotensin receptor blocker & $8(32 \cdot 0 \%)$ & $1(20 \cdot 0 \%)$ & $9(30 \cdot 0 \%)$ & $5(6 \cdot 7 \%)$ \\
\hline
\end{tabular}




\begin{tabular}{|c|c|c|c|c|}
\hline Anti-hypertensive therapy & $8(32 \cdot 0 \%)$ & $1(20 \cdot 0 \%)$ & $9(30 \cdot 0 \%)$ & $8(26 \cdot 7 \%)$ \\
\hline Inhaler & 0 & 0 & 0 & $2(6 \cdot 7 \%)$ \\
\hline Insulin & $1(4 \cdot 0 \%)$ & 0 & $1(3 \cdot 3 \%)$ & $2(6 \cdot 7 \%)$ \\
\hline Oral anticoagulants & 0 & 0 & 0 & $2(6 \cdot 7 \%)$ \\
\hline Oral antidiabetics & $5(20 \cdot 0 \%)$ & 0 & $5(16 \cdot 7 \%)$ & $3(10 \cdot 0 \%)$ \\
\hline Proton pump inhibitors & 0 & 0 & 0 & $6(20 \cdot 0 \%)$ \\
\hline Steroids & 0 & 0 & 0 & $2(6 \cdot 7 \%)$ \\
\hline \multicolumn{5}{|l|}{ Signs and symptoms } \\
\hline Fever & $22(88 \cdot 0 \%)$ & $4(80 \cdot 0 \%)$ & $26(86 \cdot 7 \%)$ & $28(93 \cdot 3 \%)$ \\
\hline Dry cough & $14(56 \cdot 0 \%)$ & $2(40 \cdot 0 \%)$ & $16(53 \cdot 3 \%)$ & $12(40 \cdot 0 \%)$ \\
\hline Diarrhoea & $5(20 \cdot 0 \%)$ & 0 & $5(16 \cdot 7 \%)$ & 0 \\
\hline Fatigue & $5(20 \cdot 0 \%)$ & $2(40 \cdot 0 \%)$ & $7(23 \cdot 3 \%)$ & $7(23 \cdot 3 \%)$ \\
\hline Myalgia & $4(16 \cdot 0 \%)$ & 0 & $4(13 \cdot 3 \%)$ & 0 \\
\hline Anorexia & $2(8 \cdot 0 \%)$ & 0 & $2(6 \cdot 7 \%)$ & $1(3 \cdot 3 \%)$ \\
\hline \multicolumn{5}{|l|}{$\begin{array}{lll}\text { Respiratory } & \text { support } & \text { upon } \\
\text { enrolment } & & \end{array}$} \\
\hline Invasive ventilation & 0 & $1(20 \cdot 0 \%)$ & $1(3 \cdot 3 \%)$ & 0 \\
\hline $\begin{array}{l}\text { Continuous positive airway } \\
\text { pressure/non-invasive ventilation }\end{array}$ & $25(100 \cdot 0 \%)$ & $4(80 \cdot 0 \%)$ & $29(96 \cdot 7 \%)$ & $30(100 \%)$ \\
\hline $\begin{array}{l}\text { Time to start of ventilation from } \\
\text { hospitalisation, days } \\
\text { Median }(\mathrm{IQR})\end{array}$ & $2(1-3)$ & $3(3-3)$ & $2(1-3)$ & $1(1-2)$ \\
\hline \multicolumn{5}{|l|}{$P P$ arterial $\mathrm{O}_{2}$ ffraction inspired $\mathrm{O}_{2}$} \\
\hline Median (IQR) & $\begin{array}{l}132 \cdot 00 \\
(92 \cdot 86-154 \cdot 00)\end{array}$ & $\begin{array}{l}96 \cdot 00 \\
(95 \cdot 00-96 \cdot 00)\end{array}$ & $\begin{array}{l}109 \cdot 17 \\
(92 \cdot 86-153 \cdot 00)\end{array}$ & $\begin{array}{l}121 \cdot 50 \\
(86 \cdot 67-224 \cdot 00)\end{array}$ \\
\hline
\end{tabular}


$\mathrm{ACE}=$ angiotensin-converting enzyme. $\mathrm{IQR}=$ interquartile range.

Table 2: Baseline laboratory and haematology parameters for the matched-control cohort and siltuximab-treated patients

\begin{tabular}{|c|c|c|c|c|}
\hline & $\begin{array}{l}\text { Siltuximab-treated } \\
\text { patients, IMV } \\
n=5\end{array}$ & $\begin{array}{l}\text { Siltuximab-treated } \\
\text { patients, CPAP/NIV } \\
n=25\end{array}$ & $\begin{array}{l}\text { All siltuximab patients } \\
\mathbf{n}=\mathbf{3 0}\end{array}$ & $\begin{array}{l}\text { Control overall } \\
\mathrm{n}=\mathbf{3 0}\end{array}$ \\
\hline \multicolumn{5}{|l|}{$\begin{array}{l}\text { Haematological parameters } \\
\text { Median (IQR) }\end{array}$} \\
\hline $\begin{array}{l}\text { WBC, median absolute } \\
\text { number/ } \mu \mathrm{L}(\mathrm{IQR})\end{array}$ & $7450 \cdot(5500-16 \square 870)$ & $\begin{array}{l}8550 \\
(6700-10 \square 430)\end{array}$ & $\begin{array}{l}8515 \\
(6700-10 \square 470)\end{array}$ & $\begin{array}{l}8295 \\
(6070-10 \square 930)\end{array}$ \\
\hline $\begin{array}{l}\text { Haemoglobin, median } \mathrm{g} / \mathrm{dL} \\
(\mathrm{IQR})\end{array}$ & $\begin{array}{l}14 \cdot 70 \\
(13 \cdot 40-16 \cdot 00)\end{array}$ & $\begin{array}{l}13 \cdot 30 \\
(12 \cdot 60-14 \cdot 30)\end{array}$ & $\begin{array}{l}13 \cdot 40 \\
(12 \cdot 60-14 \cdot 40)\end{array}$ & $\begin{array}{l}13 \cdot 60 \\
(11 \cdot 50-14 \cdot 80)\end{array}$ \\
\hline \multirow[t]{2}{*}{$\begin{array}{l}\text { Platelets, median absolute } \\
\text { number/ } \mu \mathrm{L}(\mathrm{IQR})\end{array}$} & $\begin{array}{l}145 \square 000 \\
(140 \square 000-153 \square 000)\end{array}$ & $\begin{array}{l}223 \square 000 \\
(167 \square 000-297 \square 000)\end{array}$ & $\begin{array}{l}215 \square 000 \\
(147 \square 000-279 \square 000)\end{array}$ & $\begin{array}{l}189 \square 000 \\
(161 \square 000-225 \square 000)\end{array}$ \\
\hline & $\begin{array}{l}\text { Siltuximab-treated } \\
\text { patients, IMV } \\
\text { n=3 }\end{array}$ & $\begin{array}{l}\text { Siltuximab-treated } \\
\text { patients, CPAP/NIV } \\
n=22\end{array}$ & $\begin{array}{l}\text { All siltuximab patients } \\
\mathbf{n}=\mathbf{2 5}\end{array}$ & $\begin{array}{l}\text { Control overall } \\
\mathbf{n}=27\end{array}$ \\
\hline $\begin{array}{l}\text { Lymphocytes, median absolute } \\
\text { number/ } \mu \mathrm{L}(\mathrm{IQR})\end{array}$ & $\begin{array}{l}860 \cdot 0 \\
(720 \cdot 0-13 \square 830 \cdot 0)\end{array}$ & $\begin{array}{l}750 \cdot 0 \\
(500 \cdot 0-880 \cdot 0)\end{array}$ & $\begin{array}{l}760 \cdot 0 \\
(540 \cdot 0-880 \cdot 0)\end{array}$ & $\begin{array}{l}750 \cdot 5 \\
(552 \cdot 5-1167 \cdot 5)\end{array}$ \\
\hline \multirow[t]{2}{*}{$\begin{array}{l}\text { Monocytes, median absolute } \\
\text { number/ } \mu \mathrm{L}(\mathrm{IQR})\end{array}$} & $\begin{array}{l}430 \cdot 0 \\
(360 \cdot 0-610 \cdot 0)\end{array}$ & $\begin{array}{l}285 \cdot 0 \\
(190 \cdot 0-390 \cdot 0)\end{array}$ & $\begin{array}{l}310 \cdot 0 \\
(200 \cdot 0-390 \cdot 0)\end{array}$ & $\begin{array}{l}427 \cdot 7 \\
(317 \cdot 1-499 \cdot 8)\end{array}$ \\
\hline & $\begin{array}{l}\text { Siltuximab-treated } \\
\text { patients, IMV } \\
\text { n=5 }\end{array}$ & $\begin{array}{l}\text { Siltuximab-treated } \\
\text { patients, CPAP/NIV } \\
n=23\end{array}$ & $\begin{array}{l}\text { All siltuximab patients } \\
\mathbf{n}=\mathbf{2 8}\end{array}$ & $\begin{array}{l}\text { Control overall } \\
n=28\end{array}$ \\
\hline
\end{tabular}




\begin{tabular}{|c|c|c|c|c|}
\hline $\begin{array}{l}\text { Neutrophils, median absolute } \\
\text { number/ } \mu \mathrm{L}(\mathrm{IQR})\end{array}$ & $\begin{array}{ll}6140 \cdot 0 & (4180 \cdot 0- \\
12 \square 500 \cdot 0) & \end{array}$ & $\begin{array}{l}7240 \cdot 0 \\
(5520 \cdot 0-9140 \cdot 0)\end{array}$ & $\begin{array}{l}7020 \cdot 0 \\
(5505 \cdot 0-9320 \cdot 0)\end{array}$ & $\begin{array}{l}7459 \cdot 1 \\
(4790 \cdot 8-9198 \cdot 0)\end{array}$ \\
\hline & $\begin{array}{l}\text { Siltuximab-treated } \\
\text { patients, IMV } \\
n=5\end{array}$ & $\begin{array}{l}\text { Siltuximab-treated } \\
\text { patients, CPAP/NIV } \\
n=25\end{array}$ & $\begin{array}{l}\text { All siltuximab patients } \\
\mathbf{n}=\mathbf{3 0}\end{array}$ & $\begin{array}{l}\text { Control overall } \\
n=30\end{array}$ \\
\hline $\begin{array}{l}\text { Laboratory parameters } \\
\text { median (IQR) }\end{array}$ & & & & \\
\hline AST, median U/L (IQR) & $114(47-114)$ & $56(43-77)$ & $56(43-89)$ & $62(40-74)$ \\
\hline ALT, median U/L (IQR) & $62 \cdot 0(51 \cdot 0-107 \cdot 0)$ & $56 \cdot 0(33 \cdot 0-77 \cdot 0)$ & $57 \cdot 5(33 \cdot 0-92 \cdot 0)$ & $36 \cdot 0(26 \cdot 0-60 \cdot 0)$ \\
\hline Creatinine, median $\mathrm{mg} / \mathrm{dL}$ & $0.960(0 \cdot 740-1 \cdot 010)$ & $0 \cdot 850(0 \cdot 710-1 \cdot 120)$ & $0.875(0 \cdot 710-1 \cdot 090)$ & $0.955(0.670-1 \cdot 330)$ \\
\hline & $\begin{array}{l}\text { Siltuximab-treated } \\
\text { patients, IMV } \\
n=2\end{array}$ & $\begin{array}{l}\text { Siltuximab-treated } \\
\text { patients, CPAP/NIV } \\
n=6\end{array}$ & $\begin{array}{l}\text { All siltuximab patients } \\
n=8\end{array}$ & $\begin{array}{l}\text { Control overall } \\
n=14\end{array}$ \\
\hline Procalcitonin, median $\mathrm{ng} / \mathrm{mL}$ & $0 \cdot 445(0 \cdot 390-0 \cdot 500)$ & $0 \cdot 840(0 \cdot 200-3 \cdot 460)$ & $0 \cdot 445(0 \cdot 285-2 \cdot 385)$ & $0 \cdot 840(0 \cdot 470-3 \cdot 080)$ \\
\hline & $\begin{array}{l}\text { Siltuximab-treated } \\
\text { patients, } \\
\text { IMV } \\
\text { n=5 }\end{array}$ & $\begin{array}{l}\text { Siltuximab-treated } \\
\text { patients, } \\
\text { CPAP/NIV } \\
\text { n=23 }\end{array}$ & $\begin{array}{l}\text { All siltuximab patients } \\
\mathbf{n}=\mathbf{2 8}\end{array}$ & $\begin{array}{l}\text { Control overall } \\
\mathbf{n}=\mathbf{2 7}\end{array}$ \\
\hline Lactate dehydrogenase, median & $520 \cdot 0(390 \cdot 0-579 \cdot 0)$ & $500 \cdot 0(382 \cdot 0-565 \cdot 0)$ & $505 \cdot 5(384 \cdot 0-567 \cdot 0)$ & $503 \cdot 0(389 \cdot 0-633 \cdot 0)$ \\
\hline & $\begin{array}{l}\text { Siltuximab-treated } \\
\text { patients, IMV } \\
n=4\end{array}$ & $\begin{array}{l}\text { Siltuximab-treated } \\
\text { patients, CPAP/NIV } \\
\text { n=24 }\end{array}$ & $\begin{array}{l}\text { All siltuximab patients } \\
\mathrm{n}=\mathbf{2 8}\end{array}$ & \\
\hline $\begin{array}{l}\text { Interleukin-6, median } \mathrm{pg} / \mathrm{mL} \\
\text { (IQR) }\end{array}$ & \begin{tabular}{|l|}
$446 \cdot 07$ \\
$1842 \cdot 63)$
\end{tabular} & $118 \cdot 95(74 \cdot 56-223 \cdot 52)$ & $\begin{array}{l}129 \cdot 86 \\
(74 \cdot 56-237 \cdot 88)\end{array}$ & \\
\hline
\end{tabular}




\begin{tabular}{|l|l|l|l|l|}
\hline & $\begin{array}{l}\text { Siltuximab-treated } \\
\text { patients, IMV } \\
\mathbf{n = 5}\end{array}$ & $\begin{array}{l}\text { Siltuximab-treated } \\
\text { patients, CPAP/NIV } \\
\mathbf{n = 2 4}\end{array}$ & $\begin{array}{l}\text { All siltuximab patients } \\
\mathbf{n = 2 9}\end{array}$ & $\begin{array}{l}\text { Control overall } \\
\mathbf{n = 2 7}\end{array}$ \\
\hline CRP, median mg/dL (IQR) & $9 \cdot 90(9 \cdot 10-15 \cdot 10)$ & $23 \cdot 05(16 \cdot 35-25 \cdot 80)$ & $19 \cdot 90(15 \cdot 10-25 \cdot 00)$ & $16 \cdot 10(12 \cdot 70-28 \cdot 70)$ \\
\hline
\end{tabular}

alanine aminotransferase. $\mathrm{AST}=$ aspartate aminotransferase. $\mathrm{CRP}=\mathrm{C}$-reactive protein. $\mathrm{IQR}=$ interquartile range. $\mathrm{WBC}=$ white blood cells.

$\mathrm{AL}$

$\mathrm{T}=$

alanine aminotransferase. AST=aspatate aminotransferase. CRP=C-reactive protein. IQR=interquartile range. WBC=white blood cells. 
Table 3: Summary of adverse events in siltuximab-treated patients

\begin{tabular}{|l|l|l|l|}
\hline & $\begin{array}{l}\text { Siltuximab-treated } \\
\text { patients, IMV } \\
\text { n=5 }\end{array}$ & $\begin{array}{l}\text { Siltuximab-treated } \\
\text { patients, CPAP/NIV } \\
\text { n=25 }\end{array}$ & $\begin{array}{l}\text { All siltuximab patients } \\
\text { n=30 }\end{array}$ \\
\hline At least one TEAE & $5(100 \cdot 0 \%)$ & $21(84 \cdot 0 \%)$ & $26(86 \cdot 7 \%)$ \\
\hline At least one SAE & $2(40 \cdot 0 \%)$ & $9(36 \cdot 0 \%)$ & $11(36 \cdot 7 \%)$ \\
\hline At least one severe TEAE & $5(100 \cdot 0 \%)$ & $21(84 \cdot 0 \%)$ & $26(86 \cdot 7 \%)$ \\
\hline Deaths & $2(40 \cdot 0 \%)$ & $8(32 \cdot 0 \%)$ & $10(33 \cdot 3 \%)$ \\
\hline $\begin{array}{l}\text { At least one AE of } \\
\text { CTCAE grading Mild }\end{array}$ & $0(0 \cdot 0 \%)$ & $3(12 \cdot 0 \%)$ & $3(10 \cdot 0 \%)$ \\
\hline $\begin{array}{l}\text { At least one AE of } \\
\text { CTCAE } \begin{array}{l}\text { grading } \\
\text { Moderate }\end{array}\end{array}$ & $11(44 \cdot 0 \%)$ & $24(40 \cdot 3 \%)$ \\
\hline $\begin{array}{l}\text { At least one AE of } \\
\text { CTCAE grading Severe }\end{array}$ & $4(80 \cdot 0 \%)$ & $20(80 \cdot 0 \%)$ & $6(20 \cdot 0 \%)$ \\
\hline $\begin{array}{l}\text { At least one AE of } \\
\text { CTCAE grading Life } \\
\text { Threatening }\end{array}$ & $2(40 \cdot 0 \%)$ & $4(16 \cdot 0 \%)$ & $10(33 \cdot 3 \%)$ \\
\hline $\begin{array}{l}\text { At least one AE of } \\
\text { CTCAE grading Death }\end{array}$ & $2(40 \cdot 0 \%)$ & $8(32 \cdot 0 \%)$ & \\
\hline
\end{tabular}

$\mathrm{AE}=$ adverse event. $\mathrm{CTCAE}=$ Common Terminology Criteria for Adverse Events. SAE=serious adverse event. TEAE=treatment-emergent adverse event. 
Table 4: Summary of adverse events of special interest stratified by grade (siltuximab-treated patients only)

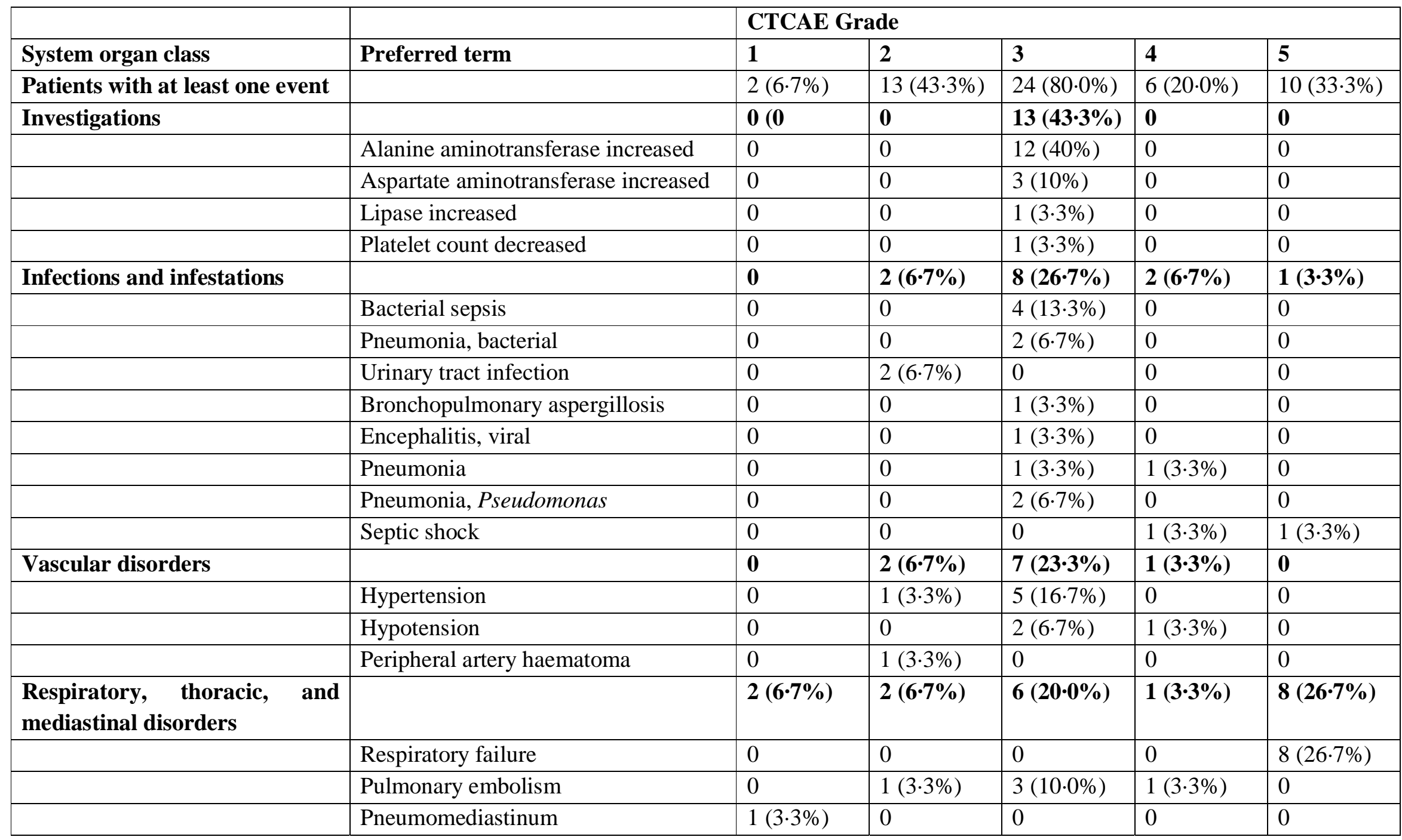




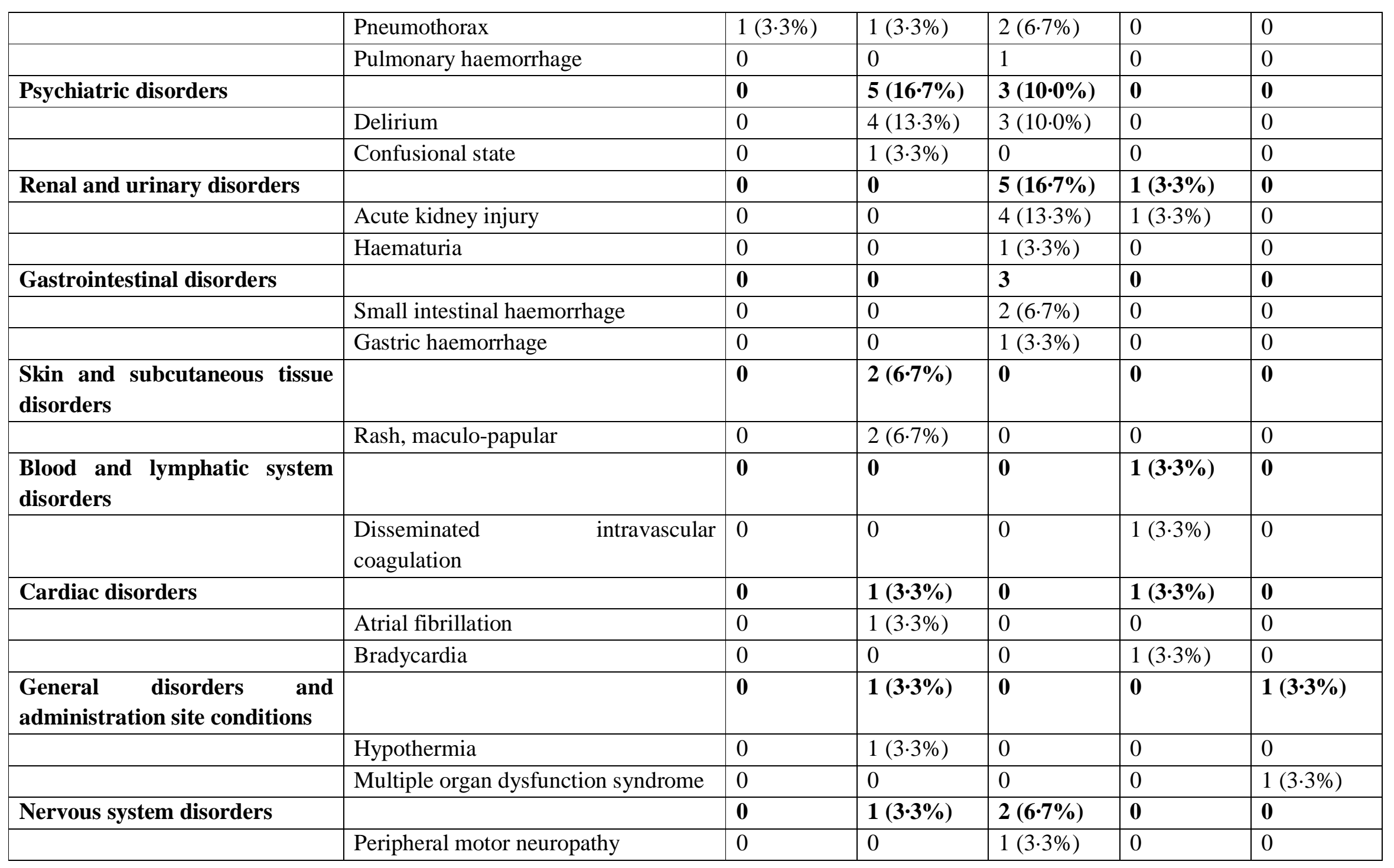




\begin{tabular}{|l|l|l|l|l|l|l|}
\hline & Transient ischaemic attack & 0 & $1(3 \cdot 3 \%)$ & 0 & 0 & 0 \\
\hline & Cerebrovascular accident & 0 & 0 & $1(3 \cdot 3 \%)$ & 0 & 0 \\
\hline & & & & & & \\
\hline
\end{tabular}

CTCAE $=$ Common Terminology Criteria for Adverse Events. 


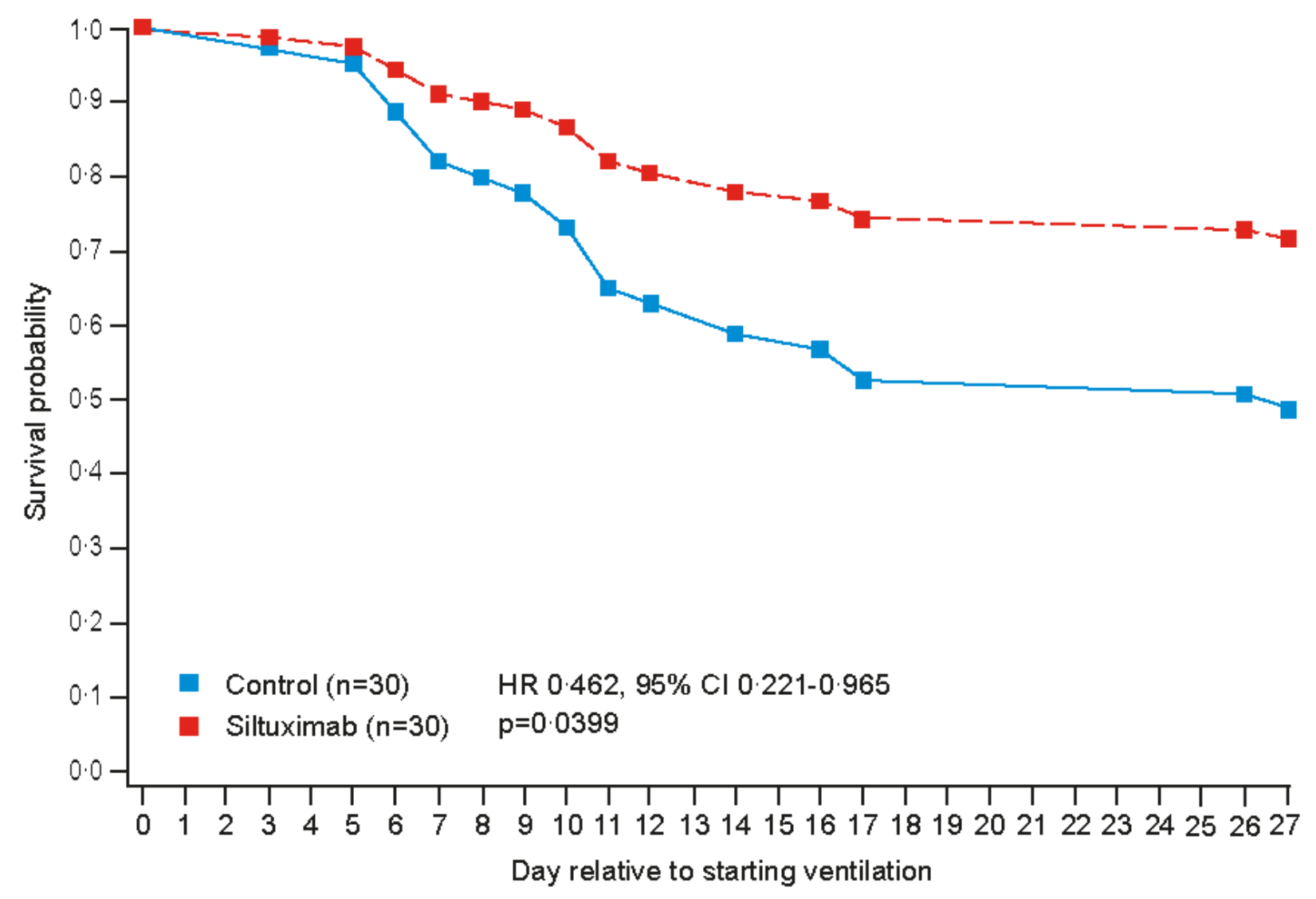

Figure 1: Probability of survival from the initiation of ventilatory support to death from any cause in siltuximab-treated patients $(n=30)$ compared with control cohort $(n=30)$ 
medRxiv preprint doi: https://doi.org/10.1101/2020.04.01.20048561; this version posted June 20, 2020. The copyright holder for this preprint (which was not certified by peer review) is the author/funder, who has granted medRxiv a license to display the preprint in perpetuity.

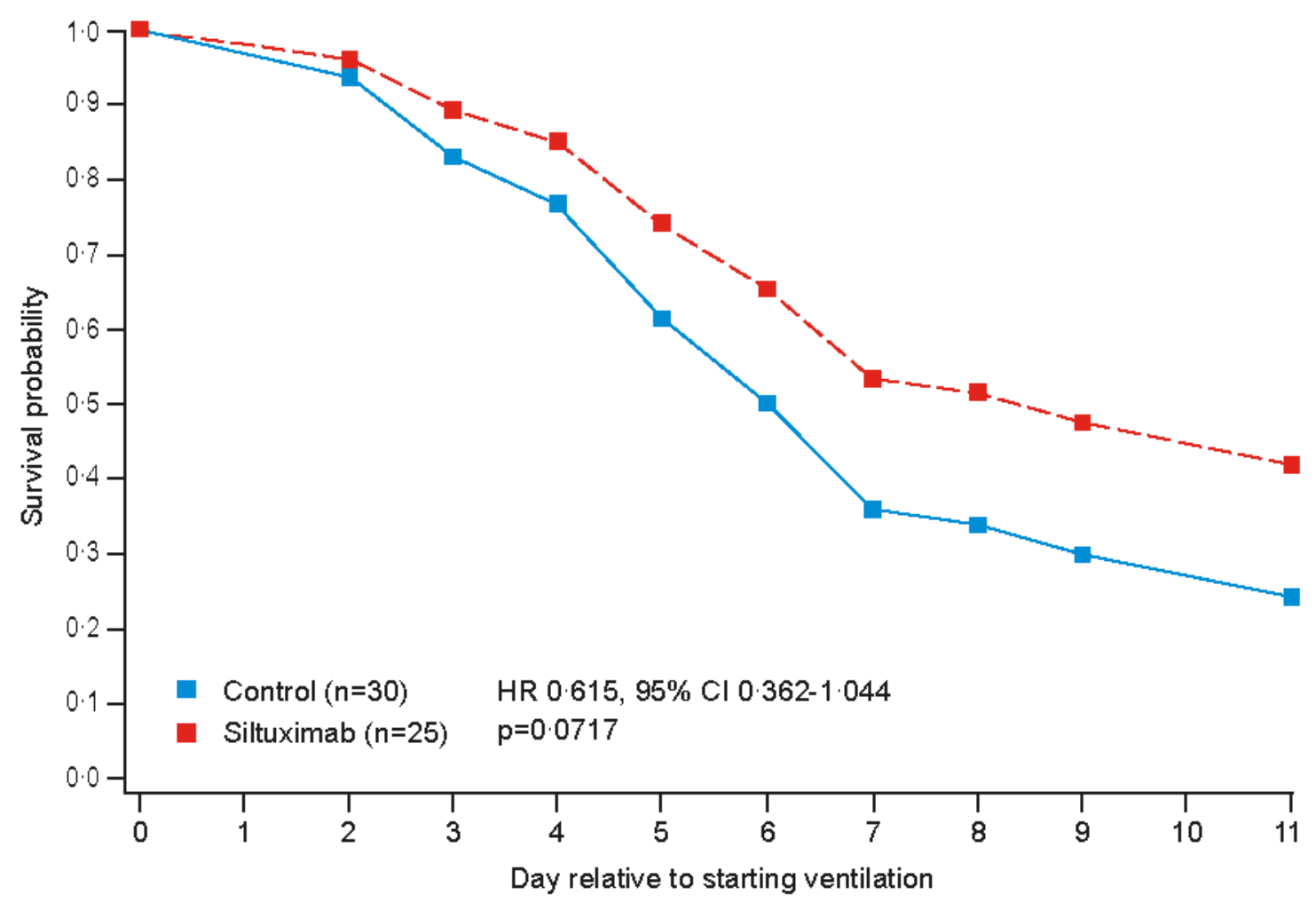

Figure 2: Probability of requiring mechanical ventilation or death in siltuximab-treated patients requiring CPAP/NIV $(n=25)$ compared with the matched-control cohort $(n=30)$ 


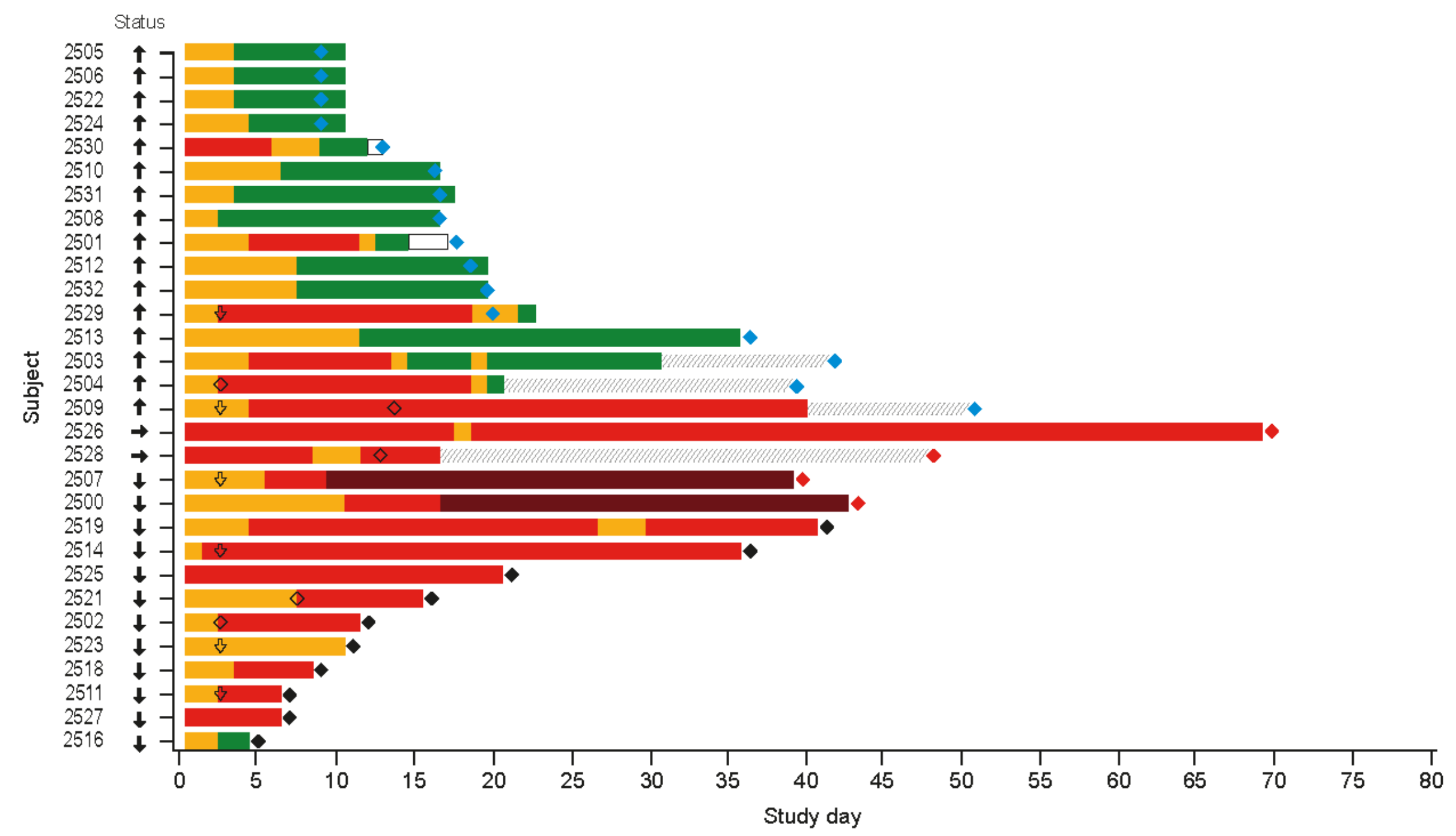

Figure 3: Changes in oxygen support and clinical outcome from day 1 through to study completion for all siltuximab-treated patients $(\mathbf{n}=\mathbf{3 0})$

$\mathrm{ECMO}=$ extracorporeal membrane oxygenation 
medRxiv preprint doi: https://doi.org/10.1101/2020.04.01.20048561; this version posted June 20, 2020. The copyright holder for this preprint (which was not certified by peer review) is the author/funder, who has granted medRxiv a license to display the preprint in perpetuity.

It is made available under a CC-BY 4.0 International license .

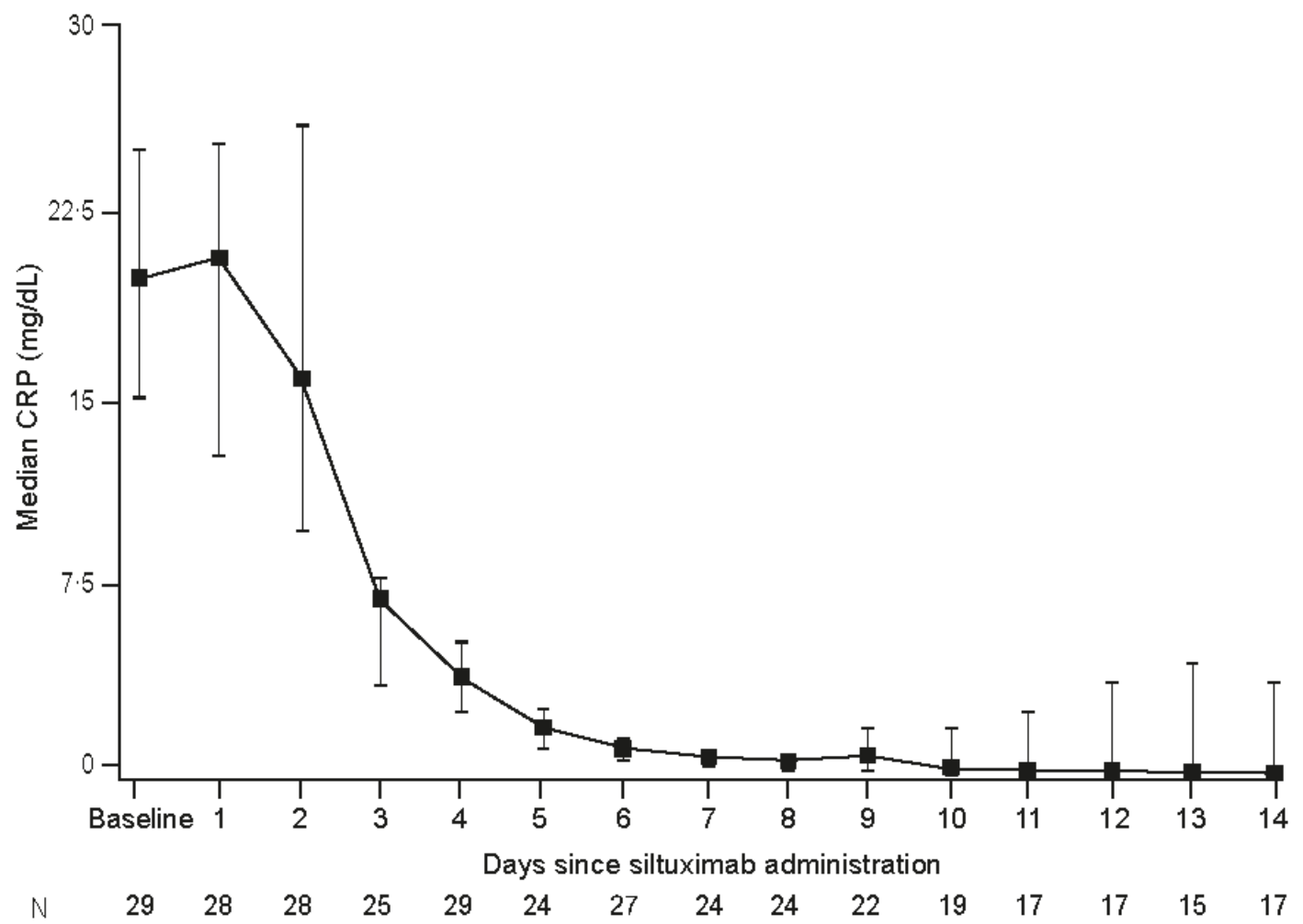

Figure 4a: Median C-reactive protein levels from baseline to day 14 in all siltuximabtreated patients 
medRxiv preprint doi: https://doi.org/10.1101/2020.04.01.20048561; this version posted June 20, 2020. The copyright holder for this preprint (which was not certified by peer review) is the author/funder, who has granted medRxiv a license to display the preprint in perpetuity.

It is made available under a CC-BY 4.0 International license .

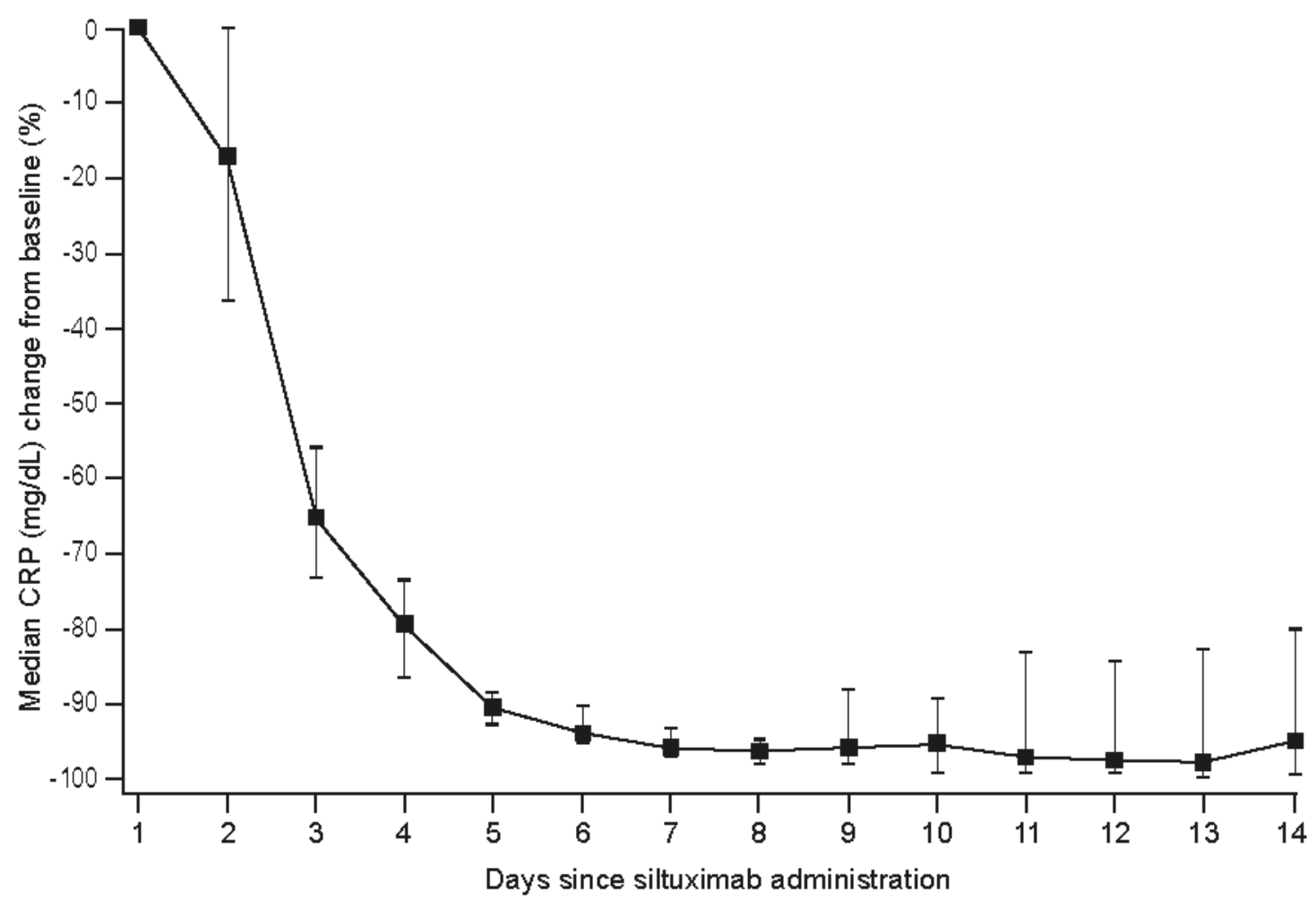

Figure 4b: Percentage change in C-reactive protein from day 1 to day 14 in all siltuximab-treated patients 